\title{
Custom Practices of English Education at the Rural Primary Schools in Bangladesh
}

\author{
Mohammad Ehsanul Islam Khan \\ Department of English, Manarat International University, Dhaka, Bangladesh \\ https://orcid.org/0000-0001-8996-3353 \\ Md. Abu Bakar Siddique \\ Department of Education, Royal University of Dhaka, Dhaka, Bangladesh \\ https://orcid.org/0000-0002-8431-7691 \\ Mohammad Nazmul Haque Shikder Shiblu \\ Department of English, Manarat International University, Dhaka, Bangladesh \\ https://orcid.org/0000-0001-5485-9185
}

\begin{abstract}
This comprehensive study dealt with the existing traditional practices of English education at rural primary schools in Bangladesh. The researchers collected data from twenty-five assistant teachers of thirteen primary schools located in the rural areas of four different districts of Dhaka and Mymensingh divisions. These English teaching participants also represent the key informants for related queries. The study used a semi-structured questionnaire with ten comprehensive and open-ended questions related to the existing teaching patterns with faceto-face interviews on the collected responses of the participants. All the data were interpreted in a qualitative approach. The study revealed the educational constrictions of the current 'English as a Foreign Language $(\mathrm{EFL})^{\prime}$ situation emphasizing the implementation of practical activities as a solution for the kids and suggested some development aspects from teachers' perspectives. The research explored the flaws of current teaching strategies and materials used in primary EFL education and recommended some practical tactics to include in the curriculum for the development of primary EFL education in Bangladesh.
\end{abstract}

Keywords: custom practices; English education; rural primary schools; children learners; methods of teaching; post-method

\section{Introduction}

EFL education significantly matters to a great extent in a developing country like Bangladesh. At all levels of education, English learning has become a 'must' for different purposes. But it is found that even after twelve years of academic study, the students cannot speak English properly as Hossain (2019) depicts that 
regardless of the high passing rate in the public examinations at the secondary and intermediate levels, the students are still found considerably weak in English. However, it happens so, owing to the lack of deploying practical approaches in different levels of EFL education, and the primary school children are the worst sufferers for it. They do not even know the imperative aspects of English in the present competitive world and lack the knowledge of its importance in future professional life. Again, the teachers of primary education also need practical development to ensure the learning outcomes and develop the learning capabilities. However, English language teaching (ELT) at the primary level in Bangladesh is a challenging phenomenon. ELT materials and methods also vary from context to context. Having an EFL context in Bangladesh, many teachers and learners face frequent difficulties to deal with the procedures of teaching and learning English. The use of digital technologies is also rare in primary EFL education. Some schools have only one projector each and some schools do not have one even. Hossain, Nessa and Kafi (2015) depicted that insufficient teaching aids and lack of subject-based training thwart to ensure effective English education.

Therefore, innovative policies are required to develop primary EFL education in Bangladesh. Therefore, the study inquires the answers to three major research questions that include "what are the existing practices of EFL education at the primary level in Bangladesh?"; "how far are these practices effective for primary level education?" and "what should be the solutions to improve English education at the primary level in Bangladesh?"

Therefore, the principal objective of this study was to reveal the constrictions of the existing practices in EFL teaching and learning at the primary level in Bangladesh with few propositions for the authority to consider the proposals feasibly for teaching English with new approaches. The study also dealt with the application of stimulating tactics to facilitate the learning with the consideration of the following interrelated key issues:

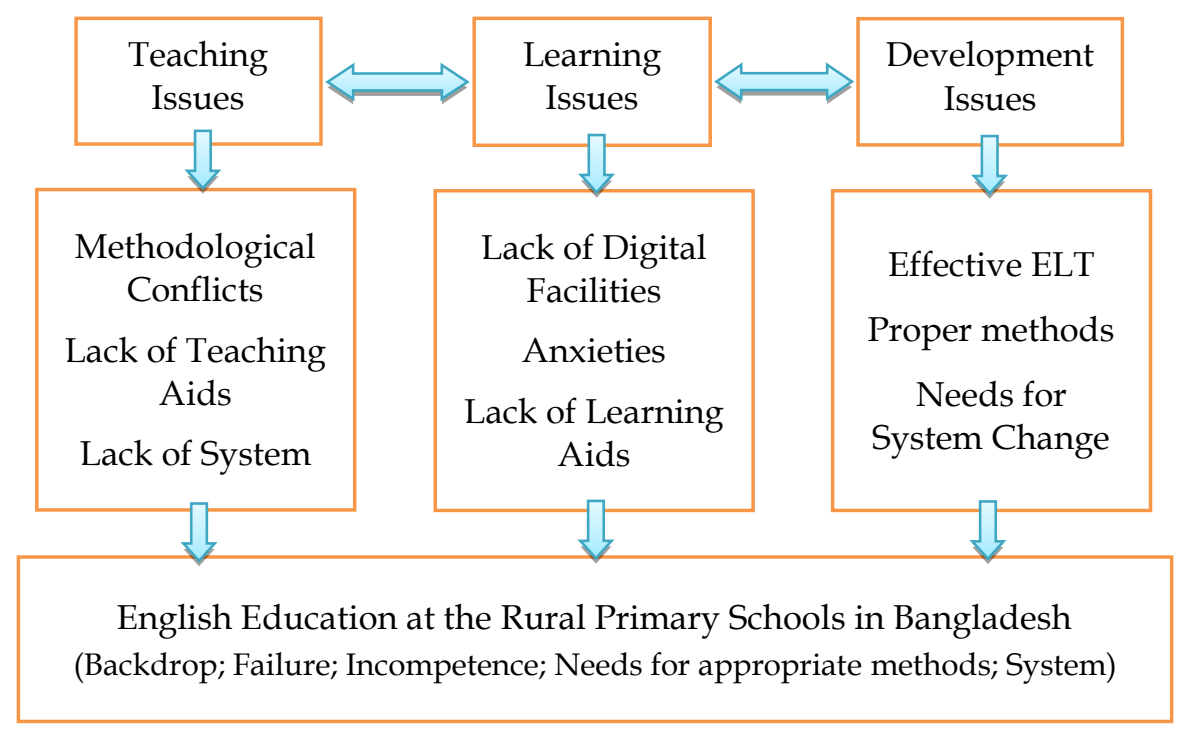

Figure 1. Interrelated issues for the development of rural primary education 


\section{Literature Review}

Communicative English emphasizes four basic skills of the English language, the students of primary schools are not usually taught these skills. They are not even familiar with the communicative aspects of the English language. The students only study as per their syllabus to get marks in the exam. The purpose of learning remains in darkness in most cases. Consequently, they also fail to cut a good figure in their secondary level education and cannot progress as per the expectations of their parents which affects their higher education as well. However, communicative language teaching (CLT) was disseminated in Bangladesh in the late 1990s, as a modern approach that focuses on spontaneous English language teaching (Monir, 2009, p.7). This approach encourages its students to practice four necessary language skills: reading, writing, speaking, and listening. Moreover, CLT is the existing approach for EFL education, but it has not reached a point of success. Besides, the implementation of CLT is "limited to the syllabus and curriculum only" (Abedin et al., 2009, p.69). However, many researchers admitted that the current EFL teaching tactics and methodologies with CLT have not been adequately appropriate (Huda, 2013; Shurovi, 2014; Khan, 2019). Particularly in the EFL classrooms of primary children, it has no specific application.

Again, Huda (2013) recommends the renovation of CLT, which has dropped to harvest predictable results. In another study, Abedin (2012) considered the practice of CLT as a disguised 'grammar-translation method' (GTM). The core concept in CLT is 'communicative competence', a term Hymes (1971) used to refer to one's ability to use language in a social context. But the scenario is that the primary students have little scopes to use the English language in their EFL classrooms. Sultana (2010) also considered that there are not sufficient numbers of qualified English teachers who are up to the mark for the primary level in Bangladesh. Many schools do not have English teachers, even (Islam, 2018). Success and failure of any educational implementation depend on the teachers as they are the key players in the classroom (Weddell, 2003). Most of the students are facing difficulties to communicate in English (Sultana, 2010). Ineffective teaching and learning processes are responsible for these situations (Hossain et al., 2015).

World Bank (2000) mentioned that majority of the children are growing up without any basic literacy and life skills. So, it is time to take steps to develop primary education. As English is one of the necessities of the current world, there is no way to ignore it. The children need proper treatment for learning English for the upcoming competitive world. Strakova (2015) opines that if procedures of teaching are adequate with the prior knowledge of the principles of students' early language learning needs, both teachers and learners can get the reward from it.

In a study, Hossain et al. (2015) found that most of the teachers complained about taking a minimum of eight classes on average in a day. So, they cannot have scopes for making lesson plans which are also considerably imperative for kid learners because a systematic approach can hasten the teaching and learning 
processes. Proper utilization of a sound methodology needs an appropriate environment. So, teaching English in the country is not an easy job for the teachers because only "a handful of children are fortunate to find such a learning environment" (Mahbub-ul-Alam, Damunupola \& Khan, 2015). Again, students' uninterest to learn English may have different causes. Hossian et al. (2015) mentioned that kids are perhaps not getting any interest in the wrong phonetics and grammar that they learn in the class. So, there is no alternatives to good teachers, although the concept of a good teacher is not defined or clear in Bangladesh due to many limitations. Therefore, the primary school teachers require a full-fledged training on pedagogically defendable approach to teach the kids. Earlier studies also did not have any suggestions to implement postmethod, which is not any specific method but a combination of approaches to facilitate teaching and learning processes. There were several research papers accomplished on different issues to develop EFL teaching at the primary level in Bangladesh. The present study broadly depicted the teachers' perspectives of custom practices of EFL education with its needs and possible solutions, as Ellis (1997) considered that the teachers might be the critical factors in classroom situations. The study presents a complete package for primary level English teaching tactics and hacks for the betterment of the children learners.

\section{Methodology}

The study followed a qualitative approach with phenomenological analyses of the interview opinions of the participants. Later, the researchers described the responses to the questions with numerical data and percentages.

\subsection{Participants}

The participants for the study were twenty-five 'Assistant Teachers' teaching English at the rural primary schools in Bangladesh, and they also acted as the key informants for the related queries. It is mentionable that still, only graduation from any background is the minimum eligibility to be a primary teacher. No participants had any certification for English language proficiency and their experience ranged from at least one year to 13 years. Table 1 shows the demographic data of the participants and the terms BA stands for 'Bachelor of Arts', MA for 'Master of Arts', MSS for 'Master of Social Science', MSc for 'Master of Science'. C-in-Ed for 'Certificate in Education', B. Ed stands for 'Bachelor of Education', M. Ed for Master of Education, and D. P. Ed for 'Diploma in Primary Education'. Degree (Pass) is a general 3-year 'Bachelor of Arts' degree which is the minimum eligibility to apply for teaching positions in the primary schools. It has various academic focuses and elective subjects. Previously, it was a 2-year degree a few years ago.

The teacher-participants are coded as T1 to T25. Table 1 shows that among the participants, 15 are female $(60 \%)$ and others are male $(40 \%)$ teachers whose experiences range from one to 13 years. Only 3 participants $(12 \%)$ completed the D. P. Ed course which is a recommended but not required course for the primary teachers. T24 was on study for that course. Four participants had a one-year Cin-Ed professional degree and T3, T5, and T25 had B. Ed. Nine participants had only a Degree (pass) course. 
Table 1: Demographic information of the teacher-participants

\begin{tabular}{|c|c|c|c|c|c|}
\hline Participants & Age & $\begin{array}{c}\text { Highest Educational } \\
\text { Qualification }\end{array}$ & $\begin{array}{l}\text { B. Ed/M. Ed/ } \\
\text { C-in-Ed/ D. P. Ed }\end{array}$ & $\begin{array}{l}\text { Experience } \\
\text { (in years) }\end{array}$ & Gender \\
\hline $\mathrm{T} 1$ & 27 & MSc in Physics & - & 2 & Female \\
\hline $\mathrm{T} 2$ & 26 & Degree (Pass) & - & 3 & Female \\
\hline T3 & 28 & Degree (Pass) & B. Ed & 4 & Male \\
\hline $\mathrm{T} 4$ & 30 & MA in English & D. P. Ed & 5 & Male \\
\hline T5 & 28 & MA in Islamic Studies & B. Ed & 6 & Male \\
\hline T6 & 26 & BA in English & - & 1 & Female \\
\hline $\mathrm{T} 7$ & 25 & Degree (Pass) & - & 2 & Male \\
\hline $\mathrm{T} 8$ & 26 & Degree (Pass) & - & 2 & Female \\
\hline T9 & 27 & M.Sc. in Chemistry & - & 3 & Female \\
\hline $\mathrm{T} 10$ & 34 & MA in Economics & C-in-Ed & 9 & Male \\
\hline T11 & 31 & BA (Honors) in English & C-in-Ed & 5 & Female \\
\hline T12 & 32 & MA in English & D. P. Ed & 5 & Female \\
\hline $\mathrm{T} 13$ & 30 & Degree (Pass) & - & 3 & Female \\
\hline T14 & 29 & MSS in Sociology & C-in-Ed & 2 & Male \\
\hline $\mathrm{T} 15$ & 25 & BA (Honors) in English & - & 2 & Female \\
\hline T16 & 32 & BA (Honors) in English & - & 7 & Female \\
\hline T17 & 29 & Degree (Pass) & D. P. Ed & 5 & Male \\
\hline T18 & 27 & Degree (Pass) & - & 2 & Male \\
\hline T19 & 28 & MA in English & - & 3 & Female \\
\hline $\mathrm{T} 20$ & 38 & Degree (Pass) & C-in-Ed & 13 & Female \\
\hline $\mathrm{T} 21$ & 26 & BA (Honors) in English & - & 1 & Male \\
\hline $\mathrm{T} 22$ & 33 & MSS in Political Science & - & 8 & Male \\
\hline $\mathrm{T} 23$ & 28 & BA (Honors) & - & 2 & Female \\
\hline $\mathrm{T} 24$ & 27 & MA in English & D. P. Ed (in progress) & 3 & Female \\
\hline $\mathrm{T} 25$ & 30 & Degree (Pass) & B. Ed & 2 & Female \\
\hline
\end{tabular}

\subsection{Data collection}

The researchers randomly selected thirteen rural primary schools from the districts of Dhaka and Mymensingh divisions of Bangladesh to collect data from the respondents. The tools of the study were a semi-structured questionnaire survey of ten open-ended questions and face-to-face interviews. The questionnaire was served to the selected English teaching participants who were available during the time of the study. Later, the researchers interviewed the participants directly on their chosen answers to have their justification.

\subsection{Data analysis}

The data were analyzed in a qualitative approach to bring out the custom practices of EFL education suggesting some post method tactics to facilitate the teaching and learning procedures in comparison to previous significant studies. The researchers preferred descriptive analysis to interpret the information.

\subsection{Integrity and transferability}

Before conducting the questionnaire survey and interview sessions, the researchers informed the participants about the objectives and probable outcomes of the study and the professional qualification of the researchers to keep integrity. The researchers were impartial in transmuting the statements given by the participants asking for clarification as required. Each study-phase was outlined effusively in the explanation to corroborate transferability. 


\section{Findings and discussion}

\subsection{Methods for teaching English}

The present scenario in Bangladesh shows that for teaching English in primary schools, 'communicative language teaching (CLT)' has been adopted. But in this study, the participants showed different views. Figure 2 shows that $16 \%$ of participants ticked 'other'. However, none of them could define the activities of the 'other' method during the face-to-face interview session and $64 \%$ of participants marked the CLT method that focuses on the four skills of the English language.

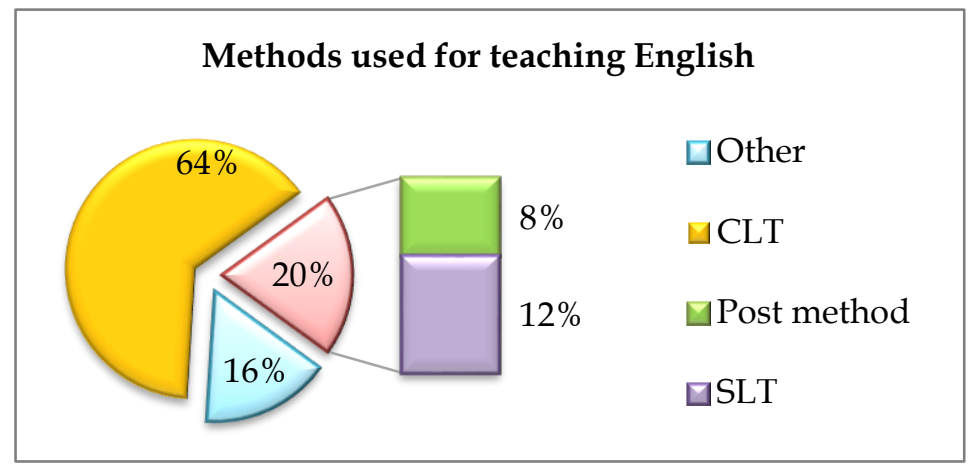

Figure 2. Methods used by the participants to teach English

The opinions of eleven participants were almost similar that in Bangladesh, CLT is not successful what Poddar (2016) also mentioned earlier that CLT is not implementing in Bangladesh according to its actual concept. They were also found in similar opinion with Mahbub-ul-Alam et al. (2014) that CLT needs modification. The current view is that the classrooms are still teacher-centred. Learners' involvement is also not enough, and their fluency is still out of concern, and classroom works are uncommunicative. Probably, this CLT method has not been successful because there is little knowledge about CLT among the teachers and the school authorities are not concerned about these matters. The grammar-translation method (GTM) method is being focused broadly ignoring CLT and post method tactics. For these reasons, the CLT might not have been successful in increasing communicative competence in English. However, postmethod is both teacher and learner cantered pedagogy (Kumaravadivelu, 2001) that can foster English education for the primary children. Notably, 20\% of teachers are also using post-method $(8 \%)$ and situational language teaching $(12 \%)$ besides using CLT in the classroom. It implies the need for an easy-going method, probably the "post-method" which is "beyond all methods" for teaching a language that facilitates the teaching and learning process with more flexibility (Kumaravadivelu, 1994).

T17 directly confessed stating "we have no idea about post method." T18 told, "we are doing our job as per the situational needs". T8 opined "we are not familiar with the post method." T9 also expressed that "we have not heard of post-method even". While post method arose to confirm the need for a most appeasing way of teaching English free from the method-based limitations with three pedagogic parameters: particularity, practicality, and possibility, most of the participants were found indifferent in this regard. 


\subsection{Teaching aids beyond textbooks}

Educational virtue cannot be found in teacher education if it is limited to educational theory only. Like other countries, Bangladesh also needs to improve the status of primary education. Training in English for primary teachers is one of the prime concerns. Teachers usually attend training about the implementation of materials in English classrooms, but all the schools are not providing sufficient materials to the teachers. However, conducting classes following the lessons learned from the training session in classrooms is another exigent challenge for the teachers.

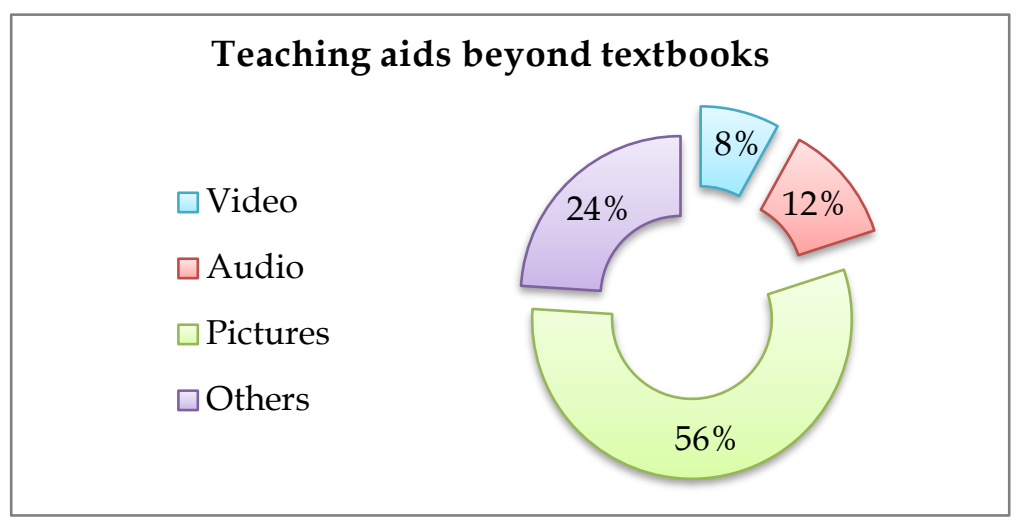

Figure 3. Teaching aids used by the teachers beyond textbooks

Figure 3 shows that $76 \%$ of participants chose audio (12\%), video (8\%), or visual materials $(56 \%)$. The teachers hardly use audio-visual materials. T3 opined that "though we extensively use the textbook to reach instructional objectives, various instructional materials are also important for better learning outcomes".

T4 added that "such materials also improve the quality of education and stimulate learners' interest to learn". In this regard, T5 opined that "we use different pictures, though not always, in the language classrooms beyond textbooks" and T6 added that "we cannot have scopes to show video materials all the time".

T20 opined that "we use different supportive materials. Still, the communicative situation is still poor in their classes." T13 and T14 showed similar assessments. T25 stated that "we use video materials especially when we need to prepare the kids for any competition". T7 considers that "audio-visual aids in the classroom can improve the learning situation credibly".

\subsection{Ways out for the weak learners}

Johnstone (1994) says that the motivation of children to learn a second language is significantly conditional on their societal background. Though English is not our mother language, it can be a challenging task for our learners to getting information in a language that is unfamiliar to them. Most of the time, the English language can be hard to perceive. Studying the lessons in a native language is relatively easy. In that case, a similar statement by $64 \%$ of participants opined about telling stories. However, T18 mentioned that "we tell stories to the students sometimes. But students do not understand always." 
T25 confessed the same that "the teachers have also weaknesses to tell a complete story in English without taking support from the books." T1, T5, T9, T16, T18, T23 had similar views also. However, $8 \%$ of the participants skipped the problematic text, and nobody answered for the 'writing' option. Yet, 28\% give different types of memorization tasks when the students do not understand the lesson in any way. T9 further opined that "sometimes telling short stories in the relevant topic works in a great way for understanding the context for primary learners." Participants' responses also hint to have a "flexible" approach like Canadian elementary education system (World Data on Education, 2006) in the post method. In that case, teachers must exercise a few predominant stimuli to motivate the students (Dornyei, 2001), whether it is storytelling or some other tactics of learners' involvement.

\subsection{Efficacy of situational language teaching (SLT)}

SLT is an oral approach based on a structural view of language with appropriate grammar use (Rhalmi, 2009) that emphasizes on speech, structures, and focus on a set of elementary vocabulary items which are the basis of language teaching. However, the distinction between the situational language teaching approaches from others is its stress on the portrayal of structures in situations.

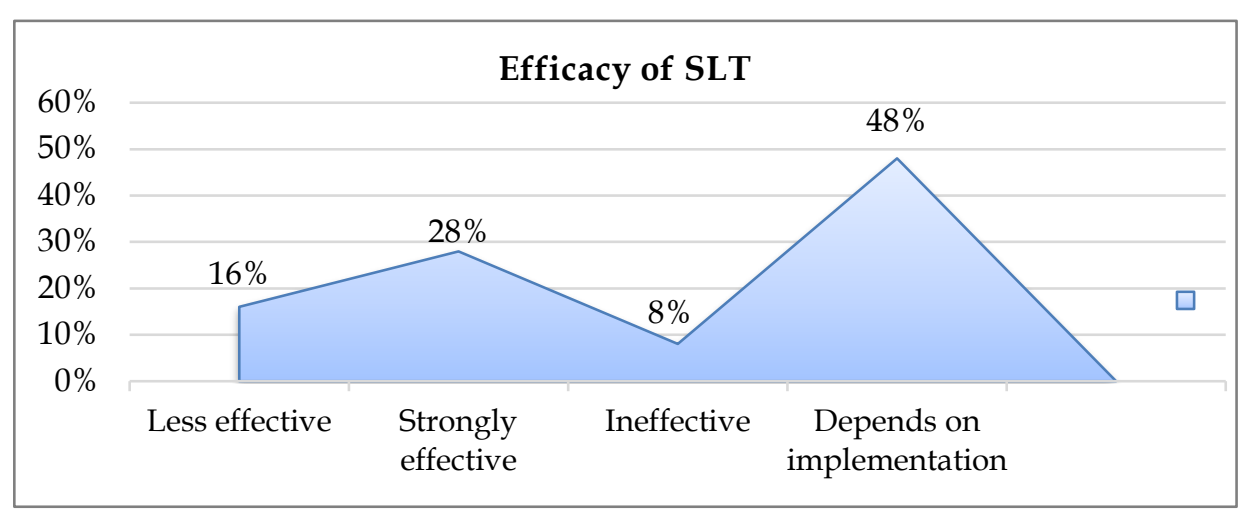

Figure 4. Efficacy of SLT in the primary EFL classroom

Figure 4 exposes that about $48 \%$ of participants agreed on the dependence on SLT's implementation in the classroom; about $28 \%$ said that the SLT approach is strongly effective on primary EFL learners. As we know the ultimate goal of this method can answer fast and accurately in every speech situation, with a motile control of basic structures and sentence patterns. The objectives of situational language teaching include the proper use of vocabulary items and grammar rules to attain an applied mastery over the four basic skills. T9 stated that "modified SLT can increase learner's capability to produce proper pronunciation and use of grammar. In that case, both audio and printed texts should be provided by the institution for practice before implementing SLT in the classroom". T18 opined that "the syllabus does not contain any practical tasks for numbering. Most of the students usually study for marks. They are getting good marks but they are gradually lagging from the competitive world because of not being engaged in practical tasks." T19 also agreed with this view. All these imply the needs for post method tactics in the primary syllabus significantly. 


\subsection{Ways to increase the attentiveness of the children-learners}

In case of implementing teaching methods effectively and successfully in an EFL primary classroom, it is very imperative to have a basic knowledge of child development and learning certainty to be insightfully related to English as a foreign language (EFL) education. The possible solution comes from $60 \%$ of the participants that they tell exciting stories and 32\% show colourful study materials for grabbing their attention in their EFL classroom. 8\% talked about English rhymes, and none chose non-verbal commands. During face-to-face conversations, teachers speak about audio-visual aids that the respective authority should increase the technological facilities for each class. However, the government is digitalizing the schools for technology enhanced classroom. T24 opined that "only the few model schools of government are fully equipped; whereas in general, most of the general schools are not getting the need-based facilities for teaching with audio-visual aids." T11 also agreed on a similar view. Therefore, the teachers emphasize technological support for clutching the attention of the children.

\subsection{Treating an inattentive student}

The involvement of students in the EFL classroom is inevitable and a serious concern for the primary level in Bangladesh because it is a primary obstacle in achieving sustainable educational goal. So, the study also emphasizes to ensure impartial quality education and development of lifelong learning opportunities for the children. T20 mentioned that "it is noticeable in primary level educational institutions that most of the students are inattentive in the classroom." T13 thinks that "the driving causes behind student's inattentiveness are multifaceted including students' deplorable socioeconomic conditions and poor understanding of parents towards education and their future expectations." T10 believes that "in government schools and colleges, the majority of students come from poor backgrounds. Their parents are not conscious about their children's education." T11 added that "for this reason, students do not come to school regularly; also, they are not attentive in the classroom." However, in this question, the participants were asked about the ploy they consider effective when the students are inattentive to the class. This study showed that $36 \%$ of the participants opined about involving parents to help and 36\% said that they take administrative help. In comparison, 16\% shockingly talked about ignoring the kids' inattentive behaviour which is unexpected. $12 \%$ said that they make the students practice preference organizations with easy sentences in pairs. However, T4 opined that "the teachers take necessary steps to grab the attention of students, but sometimes techniques are useful, and sometimes techniques remain ineffective." T16 informed that "class size is also a factor". T16 further suggested that "interesting video materials may be supportive for grabbing the kids' attention".

\subsection{Children learners' relief from anxieties with academic lessons}

As T10 agreed with T9's statements that, "in the primary level EFL classroom, most of the students are not comfortable with the communicative English language system due to nervousness and fear. The teachers are also dependent on the grammar-translation method to teach the target language sentences. 
Many of us still have the problems of understanding the application of the CLT approach in the class." So, the study finds the mismatch that hampers their learning and acquisition ability in the English classroom. For this reason, students are facing problems and become uneasy in the English classroom. Still, feasible discoveries came out from the study to relieve their anxiety in English language class to solve the communicative English problems. From the participants, $44 \%$ opined that educative games and sports can relieve children's anxieties in the classroom. The other $32 \%$ ticked on interesting tasks related to the lesson helps them a lot. $20 \%$ visit natural places though not frequently. One participant talked about audio-visual aids. "It is tough to control more than 20 students for a teacher outside the class whereas we have more than 50 students in a class", said T9. However, to make the students feel relax, the classroom setup can also be a bar as Hossain (2019) found $66.67 \%$ of his participants opined that the 'unfriendly sitting furniture' is an obstacle for teaching effectively in the classroom.

\subsection{Improving reading and writing skills of the kids}

Communicative English is a modern approach to spontaneous learning (Rahman, 2008). Through this method, students are inspired to practice four necessary skills of the language: reading, writing, speaking and listening. Reading and writing are central skills for learning the communicative English language. At present, English education at the primary level has not been up to the standard in Bangladesh. Most of the students are facing difficulties to read and write in English. T12 talked about "classroom drills, particularly repetition that can emphasize on the rote learning of the lessons"; though T1 considers this "less understandable" and T3 exposes that "repetition lacks the use of communicative English in real-life situations".

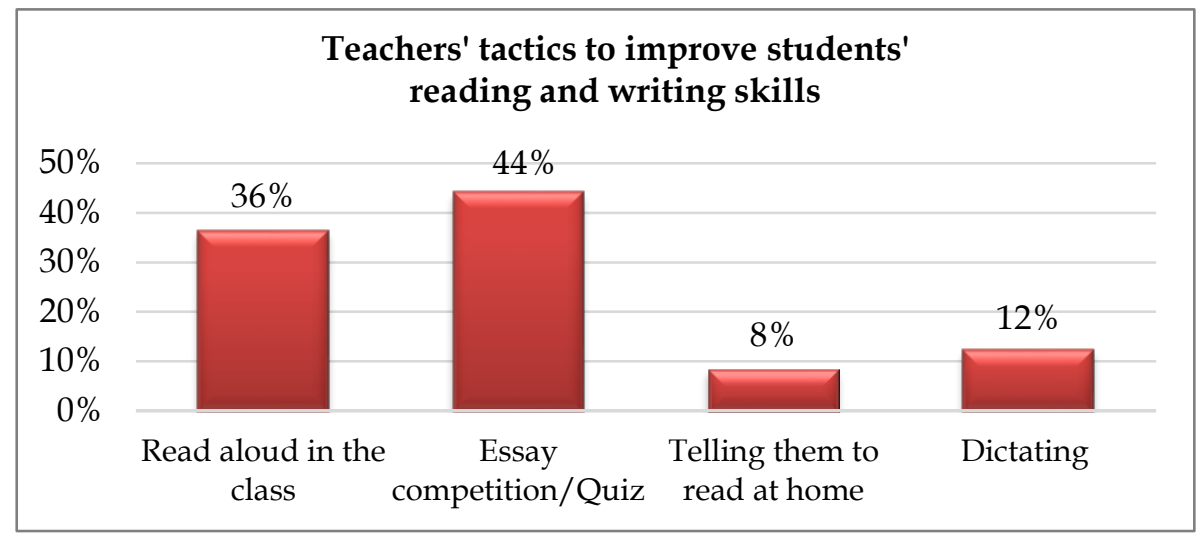

Figure 5. Tactics used by the teachers to improve reading and writing skills

Figure 5 shows that among the participants, $44 \%$ of them opined that they prefer to give students 'essay competition or quiz' and 36\% alleged that "read aloud in the classroom" is an effective way to improve reading and writing skills for the kid learners.

\subsection{Developing listening and speaking skills}

In Bangladesh, most of the students can speak and express themselves in Bengali, but they lack adequate skills in listening and speaking in the English 
language. The reasons behind these common problems are unfamiliar vocabulary, colloquial expression, and different ranges of accent, speech rate, and other learning obstacles, contextual or personal, and so on. To rectify this situation, $36 \%$ of participants suggested drills, and nobody shows English cartoons whereas $60 \%$ of participants said that they make situational conversation practice to develop the listening and speaking skills of the learners as depicted in figure 6 .

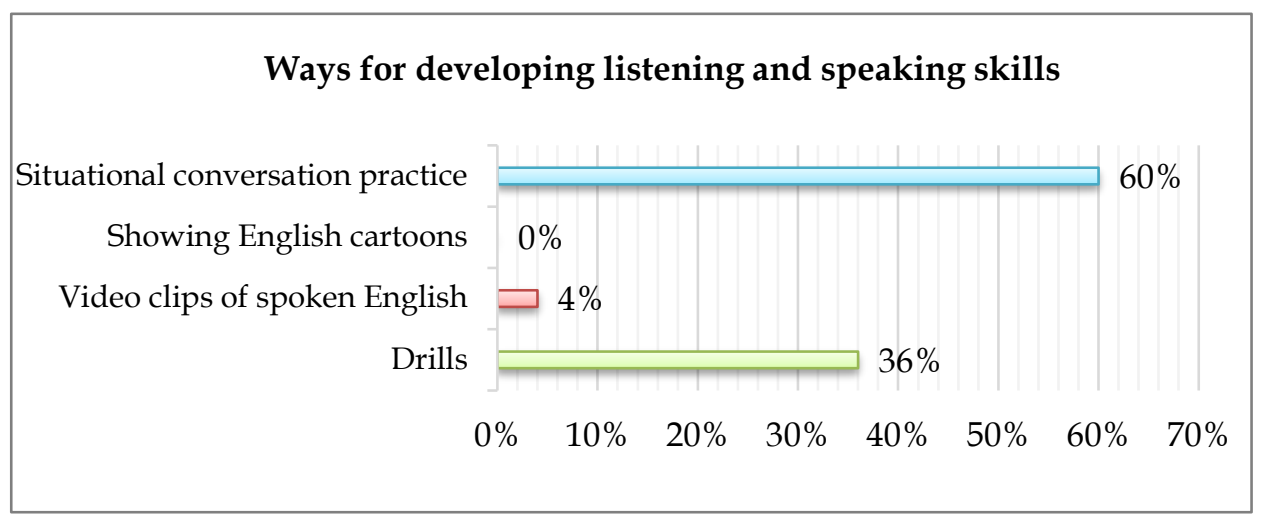

Figure 6. Ways for developing listening and speaking skills

T22 confirmed that "I teach the frequently used expressions in the class". T21 also stated that "I use everyday dialogues for listening and speaking skills". T22 added that "most of the students still do not get the meaning of those sentences and dialogues. Sometimes, they understand but cannot speak". But such dialogues are crucially beneficial to the students in the classroom and, Vrikki et al. (2019) mentioned that the teachers usually play to enable such conversations in the classroom. For that, they need proper training and professional development.

But some participants (T5, T6, T14, and T17) opined a similar statement in the interviews that their training outcomes are not effective always and there is no monitoring system after receiving the training whether the teachers utilize their learning from the training in the classrooms appropriately or not. T17 further added that "for this, many of us become idle and do not deploy our training outcomes upon the learners. It is indeed our failure."

\subsection{Constrictions of effective EFL education at the primary level}

In the current view, the primary education system in Bangladesh is facing various types of limitations, which is multifarious due to economic, sociocultural, political, regional, and religious factors. In the teacher-student ratio, the number of qualified and trained teachers also poses a significant challenge towards achieving the destination of universal primary education.

Figure 7 exposes this scenario that $40 \%$ of the participants noticed that "the lack of teachers' training" and $24 \%$ said "inadequate teaching aids" are the fundamental limitations of teaching effectively at the primary level. Teacher training is a crucial issue in the present situation in prior learning. So, it is imperative to keep attention on the teacher training system in Bangladesh and to identify the capacity and implementation gaps of the training module. 


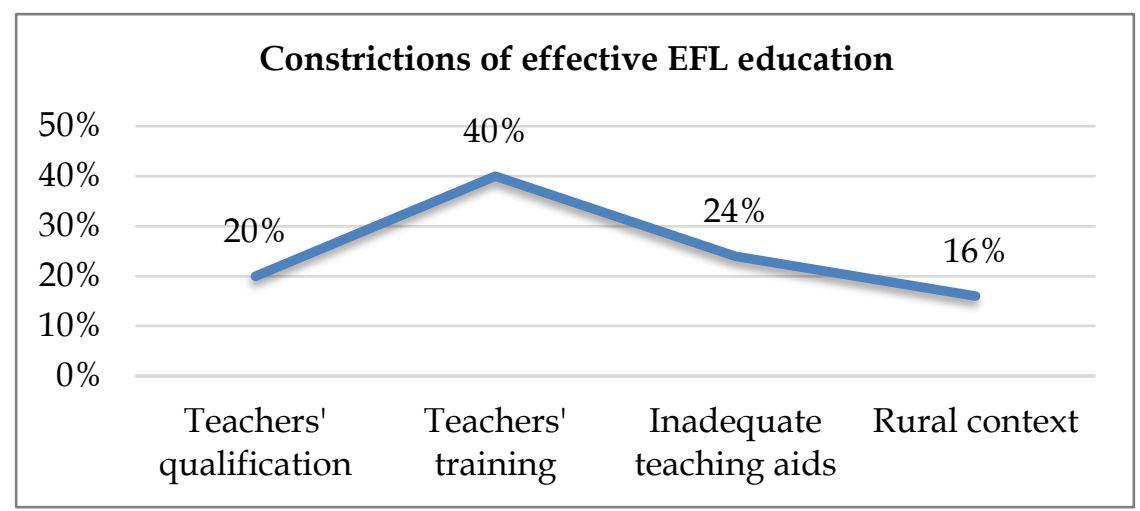

Figure 7. Constrictions of effective EFL education

However, during the interview, a participant (T13) mentioned that "the teacher appointment system still remains general. It is not mandatory to be a graduate in English background to teach English at the primary level in Bangladesh." A teacher (T14) from the same institution also emphasize the issue that "the English and Mathematics should be taught by the teachers having respective study backgrounds."

\section{Conclusion}

The present study concludes with the fact that the primary students are getting fewer opportunities to use English properly in their social and classroom environments. In this situation, it is quite challenging for them to achieve necessary English skills. Consequently, the primary EFL education level in Bangladesh has received a very shallow standard. Students are facing problems in communicating in English. The application of teaching methods is not appropriate also. Besides, the classroom facilities are deplorable to ensure a comfortable learning environment. All four skills require equal importance in the assessment procedure, and students should be allowed to develop these four skills as an inseparable part of their learning process through the academic syllabus. However, the study cannot be generalized for all schools as there are thousands of primary schools in Bangladesh, and there are many city schools whose primary education standard is very high. The researcher found several loopholes to study further with primary level education in Bangladesh. Some of the participants talked about the psychological factors of the children that are subjected to resolve. Another fact is that the low educational, or economic background of many children's parents put a negative impact on the children's minds, so very often children do not get motivation at home. Therefore, the study for motivational orientations, neuro-linguistic issues, and off-site impacts of their families can stimulate future researchers to investigate further. Finally, the study urges that the government should take initiatives for making yearround lesson plans for English teachers and include different practical activities in the primary level syllabus from the propositions of this paper to improve primary English education further. Otherwise, it is indeed challenging to ensure proper education in a densely inhabited country like Bangladesh. In this regard, the government can involve the teacher-educators of national and international exposures for a systematic series of supportive lesson plans for both the teachers and the learners as well. 


\section{Recommendations}

In Canada, "the elementary school curriculum emphasizes the basic subjects of language" (World Data of Education, 2006). The best way for the children to learn English is in a natural setting, but this is not always easy in Bangladesh. Teachers can also encourage the students to learn freely, as Woodhouse (2011) considers that stirring the students is an essential aspect of teachers to teach. However, this study presents the following propositions to foster primary EFL education with particular focuses on rural primary schools:

a. Talk: Talk can be an excellent solution for teaching English to primary school children (Johnston, 2015). So, the teachers must interactive with different types of talks in the classroom for letting the children be courageous to speak in English to be motivated credibly. Alexander (2006, p.5) considers such an idea that only oral interaction can help "teachers teach and children learn", (also cited in Johnston, 2015). However, the teachers should ensure a dynamic comfort zone for shy students to talk. It is a very crucial task for a teacher, but there are no other options except creating a student-friendly environment where shy or nervous students feel at home to speak English. Bosacki, Rose-Krasnor and Coplan (2014, p.258) also emphasize this 'emotional comfort level within the classroom'.

b. Use of autonomous learning activities: Playing games and watching English movies are independent learning options (Mehdiyev, 2020) to learn vocabulary. Students can play different games with cards, such as 'memory' with pictures and words, or even flashcards. Children also learn through songs as they become sensitive while listening to music. So, kids' English songs can be useful for teachers. Moreover, the texts of children's literature can develop their listening power. Gulec and Durmus (2015) found that the events performed with using the literary works for children to improve students' listening skills generated positive results.

c. Storytelling: Telling stories can be logically useful to enhance students' enthusiasm to learn English (Wajnryb, 2003; Wright, 1995). It can also increase their active involvement in the verbal learning procedure and can be a bridge for student-teacher interactions.

d. Practical Training: Proper training of primary teachers should be implemented and confirmed. Only certificates will not function in the long run; instead, learning 'teaching' will matter. Strakova (2015) mentions that any 'fast track' training of primary teachers who need to learn 'teaching' makes a questionable result. So-called certification may create scopes for the low-quality teachers to work at the primary level. Therefore, the authority should be concerned strictly in this regard.

e. Peer-ecology: Peer-ecology is a term used for student's better learning environment in the classroom. However, Mindful teaching approaches unswervingly intend to affect peer relations in a class (Gest and Rodkin, 
2011). So, for the primary level, it is crucial to managing the students both individually and in groups for a better learning environment (Hendrickx et al., 2016).

f. Public speaking and impromptu practice: Involvement in public speaking and impromptu practice should be ensured and regularly nurtured. The researcher found no other way than engaging the children in interactive sessions; of course, the sessions must have fun and full of the symbolic use of languages. Rubin and Morreale (1996) believed that the curriculum of elementary schools needs to include public speaking, and the student's presentation skills should contribute to the final assessment in all subjects (also cited in Herbein et al., 2018).

g. Using textbooks effectively: Textbooks should be used in a post-method way to teach reading and writing to primary students. Hossain (2019) mentioned in his study that $83.33 \%$ of his participants admitted that the textbooks have enough scopes to teach reading and writing skills.

h. Teacher recruitment: Teacher employment should require the background of respective subjects and an unbiased recruitment system. Currently, the primary teachers are being selected only with a bachelor's degree from any background. The English teaching personnel should have at least a BA (honors) in English, whereas there are no compulsory rules for it now. B. Ed, D. P. Ed., or MA in English degree should get precedence in recruitments.

Besides, the study recommends removing the quota system in different categories to develop the primary education system credibly because the quota deprives many talents of teaching opportunity and employment.

\section{Acknowledgement}

The researchers are thankful to 'Hello-Teen Society' (S-13170), a Govt. registered organization for education, research, and welfare in Bangladesh for the overall support in terms of doing the study.

\section{References}

Abedin, M. M. (2012). The present mode of teaching in the ELT classes at the Higher Secondary level in Bangladesh: Is it the practice of CLT or disguised GTM? Stamford Journal of English, 7, 01-15. doi:10.3329/sje.v7i0.14459

Abedin, M., Mojlis, K., \& Akter, S. (2009). Listening skill at tertiary level: a reflection. The Dhaka University Journal of Linguistics, 2(3), 69-90.

Alexander, R. (2006). Towards Dialogic Teaching: Rethinking classroom talk (3 $\left.{ }^{\text {rd }} \mathrm{ed}\right)$. Yorkshire: Dialogos.

Bosacki, S., Rose-Krasnor, L. \& Coplan, R. J. (2014). Children's Talking and Listening Within the Classroom: Teachers' Insights. Early Child Development and Care, 184(2), 247-265. doi:10.1080/03004430.2013.781165

Chen, M. (2014). Post method Pedagogy and Its Influence on EFL Teaching Strategies. English Language Teaching, 7(5), 17-25. doi:10.5539/elt.v7n5p17.

Dornyei, Z. (2001). Teaching and Researching Motivation. New York: Longman. 
Ellis, R. (1997). Second Language Acquisition. Oxford: Oxford University Press

Gest, S. D., \& Rodkin, P. C. (2011). Teaching practices and elementary classroom peer ecologies. Journal of Applied Developmental Psychology, 32(5), 288-296, doi:10.1016/j.appdev.2011.02.004

Gulec, S., \& Durmus, N. (2015). A Study Aiming to Develop Listening Skills of Elementary second Grade Students. Procedia-Social and Behavioral Sciences, 191(1), 103-109.

Hendrickx, M.M.H.G., Mainhard, M. T., Boor-Klip, H. J., Cillessen, A. H. M. \& Brekelmans, M. (2016). Social dynamics in the classroom: Teacher support and conflict and peer-ecology. Teaching and Teacher Education, 53, 30-40, doi:10.1016/j.tate.2015.10.004

Herbein, E., Golle, J., Tibus, M., Schiefer, J., Trautwein, U., \& Zettler, I. (2018). Fostering elementary school children's public speaking skills: A randomized controlled trial. Learning and Instruction, 55, 158-168, doi:10.1016/j.learninstruc.2017.10.008

Hossain, M. A., Nessa, M., \& Kafi, M. A. (2015). Challenges of Teaching English Language at the Primary Level Schools in Bangladesh. Banglavision Research Journal, 15(1), 07-18.

Hossain, M. R. (2019). Teaching and Learning Challenges of the Primary English Teachers in Bangladesh. Journal of ELT and Education, 2(1), 72-78,

Hossain, S. M. S. (2019). A Decisive Study of English Language Proficiency among the Private University Freshmen in Bangladesh. Journal of ELT and Education, 2(1), 36-47,

Huda, M. E. (2013). Post Method Pedagogy and ELT in Bangladesh. Global Journal of Human Social Science, 13(7), Version-01.

Hymes, D. H. (1971). On communicative competence. In J. Pride and J. Holmes (Eds.), Sociolinguistics. Penguin, 1972. Excerpt from the paper published 1971, Philadelphia, University of Pennsylvania Press.

Islam, F. (2016). Effectiveness of Communicative Language Teaching at Primary Level in Bangladesh. Published Dissertation, MA in TESOL program, BRAC University. Retrieved from http://hdl.handle.net/10361/6493

Islam, S. M. A. (2018). Social Class Systems in Communicative Language Teaching in Bangladesh. Book chapter in Engaging in Educational Research. In R. Chowdhury, M. Sarkar, F. Mojumder, \& M. M. Roshid, (Eds.). Education in the Asia-Pacific Region: Issues, Concerns and Prospects, Springer, 44, p. 111.

Johnston, E. (May 14, 2015). Children's Engagement with Talk to Enhance Learning in the Primary School Classroom: Literature Review. The Critical Blog, Retrieved on February 22, 2020 from https://thecriticalblog.wordpress.com/2015/05/14/

Johnstone, R. (1994). Teaching Modern Languages at Primary Schools: Approaches and Implications, Practitioner MiniPaper 14. The Scottish Council for Research Education: Scotland.

Kalim, T. (2009). Instructional materials. Bangladesh Education Article. Retrieved May 11, 2019, from https:/ / bdeduarticle.com/instructional-materials/

Khan, M. E. I. (2019). Justification of Using Post-method Pedagogy at Intermediate Level in Bangladesh: Teachers' Insights. Fareast International University Journal, 2(1), 105-113.

Kumaravadivelu, B. (2001). Toward a Post-method Pedagogy. TESOL Quarterly, 35(4), $537-560$.

Kumaravadivelu, B. (1994). The Post-method condition: (E) merging strategies for second/foreign language teaching. TESOL Quarterly, 28 (1), 27-48. 
Mahbub-ul-Alam, A., Damunupola, E. S. K., \& Khan, M. E. I. (2015). Psycho-Social Quandaries of Young EFL Speakers in Bangladesh. ASA University Review, 10(1), 95-108.

Mahbub-ul-Alam, A., Zaman, F., Khan, M. E. I., \& Rahman, J. (2014). Necessity of Modification in Existing Communicative Language Teaching (CLT) Approach: Bangladesh Perspective, IOSR-JHSS, 19(10), Version-VII, pp. 52-56, doi:10.9790/0837-191075256

Mamun, S. A. K. (December 24, 2018). What can we do to keep children in school? The Daily Star. Retrieved December 29, 2019, from https://www.thedailystar.net/opinion/education/news/what-can-we-dokeep-children-school-1677874.

Mehdiyev, E. M. (2020). Opinions of EFL students regarding autonomous learning in language teaching. Journal of Language and Linguistic Studies, 16(2), 521-536. doi:10.17263/jlls.759241

Podder, R. (2016). Challenges of Implementing CLT at Secondary Level of Education in Bangladesh. The EDRC Journal of Learning and Teaching, 1(1), 34-45.

Rahman, M. M. (June 28, 2008). Learning and teaching English. The Daily Star, Retrieved from https:/ / www.thedailystar.net/news-detail-43164

Rhalmi, M. (August 26, 2009). Situational Language Teaching (Oral Approach). My English Pages. Retrieved 30 February 2020 from https://www.myenglishpages.com/blog/situational-language-teaching-oralapproach/

Rubin, R. B., \& Morreale, S. P. (1996). Setting expectations for speech communication and listening. New Directions for Higher Education, 96, 19-29, doi:10.1002/he.36919969604 1996.

Shurovi, M. (2014). CLT and ELT in Bangladesh: Practice and Prospect of Speaking and Listening. Journal of Language Teaching and Research, 5(6), 1263-1268. doi:10.4304/jltr.5.6.1263-1268.

Strakova, Z. (2015). Challenges of teaching English at primary level. Procedia-Social and Behavioral Sciences, ScienceDirect, 174, 2436-2443. doi:10.1016/j.sbspro.2015.01.914

Sultana, D. (2010). Teaching English at the primary level in Bangladesh: present status, issues, and challenges. BRAC University Journal, Special Issue, Number 01.

Vrikki, M., Wheatley, L., Howe, C., Hennessy, S., \& Mercer, N. (2019). Dialogic practices in primary school classrooms. Language and Education, 33(1), 85-100. doi:10.1080/09500782.2018.1509988

Wajnryb, R. (2003). Stories: Narrative activities in the language classroom. Cambridge Handbooks for Language Teachers. Cambridge: Cambridge University Press.

Woodhouse, H. (2011). Learning for life: The people's free university and the civil commons. Issues in Social Justice, 5(1), 77-90. doi:10.26522/ssj.v5i1.993

World Bank. (2000). Improving the Quality of Primary Education in Bangladesh: A Strategy Investment Plan. Michigan: Michigan University Press.

World Data of Education. (2006). Canada. WDE, $6^{\text {th }}$ editions 2006/07, International Bureau of Education, UNESCO, Retrieved from http://www.ibe.unesco.org/sites/default/files/Canada.pdf

Wright, A. (1995). Storytelling with children. Oxford: Oxford University Press. 


\section{Appendix 1}

\section{Questionnaire for Survey and Interviews}

1) Which method are you adopting to teach EFL at the primary level at your school?
(a) CLT
(b) SLT
(c) Post-method
(d) Other

2) What types of teaching aids do you use in the language classrooms beyond textbooks?
(a) Video
(b) Audio
(c) Pictures
(d) Others

3) What is the commonest way out for your learners when they do not understand any lesson in any way?
(a) Memorization
(b) Skipping the text
(c) Writing
(d) Telling Stories

4) How far Situational Language Teaching (SLT) can be effective for your primary EFL learners?
(a) Less effective
(b) Strongly effective
(c) Ineffective
(d) Depends on implementation

5) How can you make your learners attentive in the class?
(a) Telling stories
(b) English Rhymes together
(c) Showing colourful study materials
(d) Non-verbal commands

6) Which one do you prefer to control a student when he/she is inattentive?
(a) Ignoring the kids' behaviour
(b) Concerning parents to help
(c) Preference organizations in pairs
(d) Asking for administrative help

7) Which one do you utilize most to entertain the children learners to provide them relief from anxieties with academic lessons?
(a) Audio-visual aids
(b) Games and sports
(c) Visiting a natural place with the students nearby the schools
(d) Giving interesting tasks related to the lesson

8) What step would you like most to improve the reading and writing skills of your kid learners?
(a) Read aloud in the class
(c) Telling them to read at home
(b) Essay competition/ Quiz
(d) Dictating

9) How can you develop the listening and speaking skills of your learners?
(a) Drilling
(c) Showing English cartoons
(b) Showing video clips of spoken English
(d) Situational conversation practices

10) Which one do you believe is the key limitation of teaching ELT effectively at the primary level?
(a) Teachers' Qualification
(b) Teachers' training
(c) Inadequate teaching aids
(d) Rural context 